\title{
SEVENTY-SECOND DISTRIBUTION OF INCOME FROM THE EMPRESS SHÔKEN FUND
}

Fourteen Red Cross or Red Crescent Societies in developing countries will benefit from grants totalling 423,000 Swiss francs under the seventy-second distribution of income from the Empress Shoken Fund. The money will finance activities relating to disaster preparedness, health, social welfare, first aid and youth programmes.

The National Societies were selected at a recent meeting in Geneva of the joint ICRC-Federation Commission entrusted with the distribution of the income of the Fund. The meeting was chaired by Mr. Maurice Aubert, former Vice-President of the International Committee of the Red Cross (ICRC). The delegation of the International Federation of Red Cross and Red Crescent Societies (Federation) was headed by its Acting Secretary General. Mr. George Weber. The Ambassador of Japan in Geneva, H.E. Mr. Hidetoshi Ukawa, was present at the meeting.

The grants will finance the following projects:

$\begin{array}{lcc}\text { Beneficiary } & \text { Amount in } & \text { Purpose of allocation } \\ \text { National Society } & \text { Swiss francs } & \end{array}$

Cape Verde

Chile

Costa Rica

Ecuador

Egypt
30,000 To purchase a minibus for the transport of aged people

37,000 For a CHEVROLET-ISUZU "Transporter" ambulance

12,000 To install communication links in the "Región Tres"

35,000 For a TOYOTA Hiace 4WD ambulance

35,000 For first-aid and rescue-training programmes all over the country 
Jordan

Laos

Madagascar

Pakistan

Rwanda

Sao Tome \& Principe

Solomon Islands

South Africa

Swaziland
34,000 To purchase medical equipment for a laboratory in the Ma'an district

45,000 To strengthen the capacity of the Red Cross Blood Transfusion Service

7,000 To purchase audio-visual equipment for training programmes

43,000 To purchase medical equipment for the Blood Donor Centre in Islamabad

30,000 For a TOYOTA Hiace ambulance/ minibus

20,000 Wheelchairs/tricycles for disabled persons

20,000 To purchase equipment for training and development programmes

50,000 To help finance the enlargement of the Kwanobuhle Community Centre in the Eastern Cape Region

25,000 To train first-aid instructors for programmes to be carried out throughout the country

Total $\quad 423,000$

The Fund was set up in 1912 through a gift from Her Imperial Majesty of Japan to encourage the development of humanitarian activities by National Red Cross and Red Crescent Societies. The Empress Shôken died on 11 April 1914. The Fund has received repeated gifts from the Imperial Family of Japan, the most recent one being a five million yen donation to mark the 90th birthday of Her Majesty the Dowager Empress on 6 March 1993.

Both the Japanese Government and the Japanese Red Cross Society also contribute to the Fund, the former with generous annual allocations of twenty million yen, the latter with donations on special occasions, e.g. a five million yen contribution on 8 March 1993, the 40th anniversary of the enactment of the Japanese Red Cross Law.

The interest-bearing investments of the Fund amount to 7.5 million Swiss francs. 